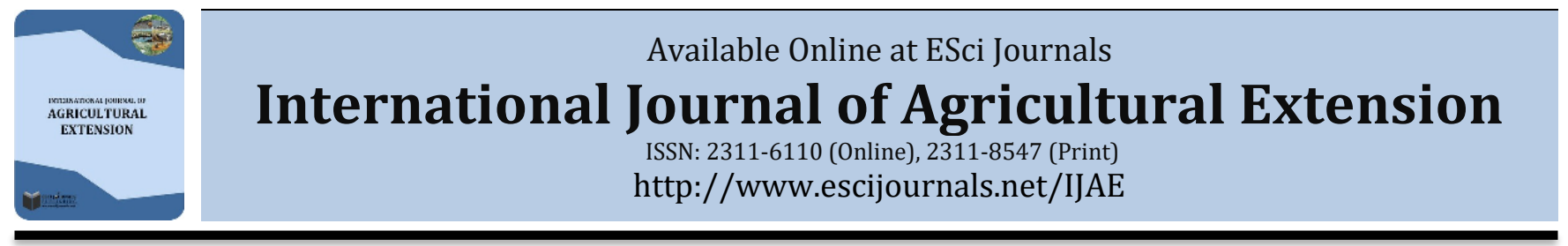

\title{
EXTENSION AND TRAINING PRACTICES: CHALLENGES FOR SMALLHOLDER CATTLE FARMERS' COMMUNITY IN THAILAND
}

\author{
Waripas Jiumpanyarach \\ School of Agricultural Economics, Chulalongkorn University, Bangkok, Thailand.
}

A B S T R A C T

The objective of this study was to analyze the impacts of an extension program (education and training practice) as perceived by smallholder cattle farmers to develop their smallholder farm practices and reduce the costs of production. The study used data from 22 participant smallholder farmers with backgrounding cattle systems. Indepth interview questionnaires were used and collected before and after providing the extension program in Saraburi province, Thailand. Two leaders of this group were selected for observation and as farm models. Environmental differences were investigated during the rainy, winter and summer seasons. This study detailed the socioeconomics of the smallholders, the characteristics and management of livestock farms. The satisfaction levels of the extension programs were also analyzed. The benefits and costs of this program were examined and developed after the program finished. The study found backgrounding cattle farms was a major livelihood within the community. The community was of low income and living in poverty. The farmers were at high levels of risk in terms of feeding costs and cattle market. The program provided knowledge to be enable the farmers to understand and develop the farm systems. Most of the smallholders agreed on the good-practice farming and group activities. The farm leaders influenced their perceptions. The farmers were encouraged to do activities together: learning cattle market information, good-practice cattle farms, and cattle rations management. The success of the extension program improved the economic community, community relationships, and community attitudes. The extension program applied to a pro-active policy. Collaboration learning activities for smallholders benefit the farmers' community. This program improves economic relationships, attitudes, and builds a sustainable agricultural community.

Keywords: Backgrounding cattle, extension program, good-practice, smallholder cattle farmers, feeding cost, social relations

\section{INTRODUCTION}

Over the last 4 decades, industrial farm systems have been introduced to developing countries. The aim was to maximize production at the least cost and develop the intensive production process. Large-scale farm systems have been developed into intensive farm systems except smallholder farms, which need support from the government and community. Smallholder cattle farms in developing countries are usually supported by government. Different factors have changed livestock systems overtime in developing countries. The demand for livestock, especially cattle, is increasing in agricultural-based countries (Worldbank 2007). This market demand has induced structural changes in cattle

\footnotetext{
* Corresponding Author:

Email: goumaoindo@yahoo.com

(C) 2018 ESci Journals Publishing. All rights reserved.
}

production, processes, and distribution. Trends in the production and consumption of meat especially in developing countries have increased over the last two decades (approximate increase of 50-100\%) (FAO 2015). Beef is imported more than exported in Thailand compared with other livestock (pork and chicken) (OAE 2015). Most smallholders sell their products to middlemen or informal markets. High quality and safety cattle standards are increasingly demanded in the market. Thus, smallholders find it difficult in the highly competitive market. The structural changes in the cattle farm business depend upon large agribusiness companies. Extension services programs $^{1}$ and

\footnotetext{
${ }^{1}$ Extension program or extension service program: An extension program or extension service program is the
} 
government policies are important and should be active for smallholder farming communities to aid them in becoming sustainable farmers. Therefore, productive grassland for beef is the best strategy for smallholder farmers to decrease the cost of production (Borges, et al., 2014 and Kamali, et al., 2016). Feeding strategy is a major activity within farm management (de Vries et al., 2015). The substituted feed rations for cattle reduce production costs and time. The outcome affects economic farm value (Opgrand, et al., 2015).

Cattle farms are a major source of livestock in Thailand and cattle are used as drought power, especially in rural areas. Generally, Thailand has two types of cattle farm systems: smallholder cattle farms and large-scale cattle farms. Most cattle farms in Thailand are small in size with systems of backgrounding ${ }^{2}$ cattle before selling on to feedlots. The factors surrounding backgrounding cattle farms impact the farms' economy, farm management and farm environment are important. The economic factors of farms include the purchase and sale prices, feed prices, and interest rates, which are very important for the smallholder farm community to become sustainable. The smallholder backgrounding cattle farm is a short-term investment, and small changes in some economic factors have great impact on profitability. The farm owners usually integrate economics and management in making the decisions that will be the most profitable for cattle backgrounding (Dicostanzo 2014). The backgrounding cattle process is a process to increase the growth rate of cattle before they are sold to a feedlot. The quality and quantity of feeding rations is necessary in the growth rate. Backgrounding cattle is a process for feeding newly weaned steers and grower rations prepares them for finishing at the feedlot (Perillat 2004). The portions of forage, mixed protein and little fat are used to increase muscle and frame. Backgrounding cattle normally develops cattle of smaller frame, for which it is of greater benefit than cattle of a larger frame. This process helps to reduce the time to develop the muscle and frame in the feedlot. Smallholder cattle farms in rural areas constitute the majority of farms in northeast Thailand.

delivery of information to farmers, including education and practices

${ }^{2}$ Backgrounding cattle: Backgrounding cattle is an intermediate stage that begins after weaning and ends before the cattle go to a feedlot.
Most of the smallholder cattle farms purchase cattle of lighter and smaller frame and the backgrounding process finishes at 100-200 kilograms in additional weight, after approximately 3-4 months when they are sold to large-scale cattle feedlot farms. The income of these smallholder cattle farmers comes from differences between purchasing prices and selling prices. The process of backgrounding is that lighter framed cattle are allowed to roam amidst public grassland close to their farms. They are fed with dried cassava, pealed cassava, and 8-percent pellet protein after the cattle return from the grassland to the farm. The number of smallholder cattle farms, comprise only 10 percent of total cattle farms in Thailand, (OAE, 2015). Large- scale farms utilize technologies and management such as disease control, pasture improvement, animal breeding, and supported markets. While smallholder farmers always face high risks regarding short-term investments and net returns on profit, large-scale farms face greater competition in larger markets.

Smallholder backgrounding cattle farm in Thailand employ various production processes due to the environment, location and prices of rations. The longterm risk of farms in rural areas impacts household economies, of which it is difficult to determine the net return and profits. Farm systems have different levels of potential productivity, economic return, and risk avoidance. Different sizes of cattle farms in Thailand prefer different farm information and government extension service programs. Extension services, especially government and academic, are directly provided to the smallholder at the farms. The services program includes accounting, forage preparation, nutrition grain, alternative grain, labour, and market. The services program aims to improve productivity and support the sustainability of the rural farm (Jiumpanyarach 2016b). The Thai government has developed a policy aiming to expand beef (live cattle) production in order to satisfy domestic and international demand and reduce the poverty of smallholder cattle farms (DLD 2014). The ASEAN economic community is impacting the demand for the cattle market in Southeast Asia, China, and other countries (DLD 2014). Demand for beef has increased from outside the country. According to the policy and Asian Economic community (ASEAN), the Thai government encouraged livestock farms to increase in both backgrounding cattle farms and feedlot cattle farms. 
Although the government has policies to increase beef production, farm owners' income has been declining. Demand for cattle and farming income has moved in the opposite direction, especially among smallholder backgrounding cattle farms. The evidence shows that the international demand for cattle in the market did not impact smallholder farms in rural areas. The reduction in feeding rations cost should be one solution for smallholder farms in rural areas in terms of farm economics. The tradition and culture of the smallholder always influences the community; thus providing knowledge is one another solution to improve both the economics and society of the smallholder cattle farm community. A public extension program is the best way for them to improve the quality of the products and community (Jetmark 2014).

Objectives: The aim of this research presents socioeconomic factors that impact smallholders of backgrounding cattle farms in Thailand. Tumbon Tandeaw, Aumphor Kangkoy, Saraburi province in Thailand was selected as the community model because of the farmers' attitude, number of smallholders, and geography of the area. This research analyzes the benefits to farmers who attended the extension program (education and training practices). The program expects to reduce the economic risks of smallholder backgrounding cattle farms and enhance community relations. This expects good practices in animal feeding rations to impact the economy, community relations, and social development of the studied area.

\section{METHODOLOGY}

A participatory approach was used. The participating farmers were given information and answered questionnaires. The participation approach is expected in such aspects as a reduction of production costs, quality of life, and agricultural sustainability. Farmers and extension agents use different sources of knowledge. The approach involves farmers and extension agents. Farmers are responsible for aspects while the extension agents introduce the necessary knowledge (Arevalo \& Ljung 2006; Van Asten et al., 2009). The approach was designed for outcome analysis and treatment. (Marquardt et al., 2009). The participating farmers are responsible for the framework, preferences, and capacity of their farms.

The treatment is more appropriate for farmers. Farmers and extension agents will choose strategies that have the most attractive opportunities and common practices.
This will most optimize the interaction and understanding between them. This method includes twenty-two smallholders' cattle farms of household questionnaires and two in-depth interviews of farm leaders chosen to participate in the program and prepared to become farm models for the community. Insights were made as to how delivery of knowledgerelated activities was undertaken by smallholder cattle farmers. These surveys generated agricultural information strategies for smallholder cattle farms. The qualitative information relies on interview, discussion, and observation.

Study Area: Tumbon Tandeaw, Aumphor Kangkoy, Saraburi province was selected because the area has many smallholders with backgrounding systems for the cattle farms. The smallholders were willing to participate in this program. The distance is approximately $100-200 \mathrm{~km}$ to the livestock market and this area contains the ingredients for cattle rations.

The economy of Saraburi province is both industrial and agricultural' however the zones between industrial and agricultural areas are not well organized. Most of the people here have moved from other regions for the industrial work while locals work in the agriculture sector. The people in the studied area live in the agricultural area and are smallholder farmers, which traditionally has smallholder backgrounding cattle farms.

Tumbon Tandeaw, Aumphor Kangkoy, Saraburi province, the studied area, is located in Northeast Thailand $\left(14^{\circ} \mathrm{N} ; 100^{\circ} \mathrm{E}\right.$.). Saraburi province is divided into 13 districts (amphor). The districts are subdivided into 111 communes (tambon) and 973 villages (muban) as shown in Figure 1. The temperature is that of a tropical climate. The annual average minimum temperature is $23-24{ }^{\circ} \mathrm{C}$, and the maximum $33-34{ }^{\circ} \mathrm{C}$. The total area covers $3,576,486 \mathrm{~km} 2$ or $2,235,304$ rai, which is approximately $0.70 \%$ of the country (Saraburi province government 2014).

Farm Selection: The study combined questionnaires and in-depth interviews during the rainy, winter, and summer seasons. The twenty-two smallholder cattle farms with backgrounding systems were selected to study in Tumbon Tandeaw, Aumphor Kangkoy, Saraburi province based on their locations and their farm community activities. Two farm leaders were selected, named Winai-tiwa and Marnop, to do the in-depth interviews and their backgrounding cattle system and 
management observed. These two farms were selected based on farm management, attitudes, and number of cattle, which had between 30 and 40 cattle in the farm.
Also, they were well planning, organized, and recorded the process such as in-weight, pay-weight, feeding time, and feeding costs.

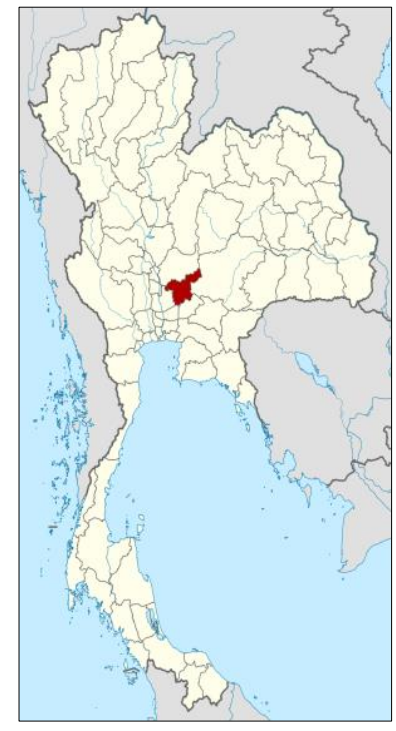

A

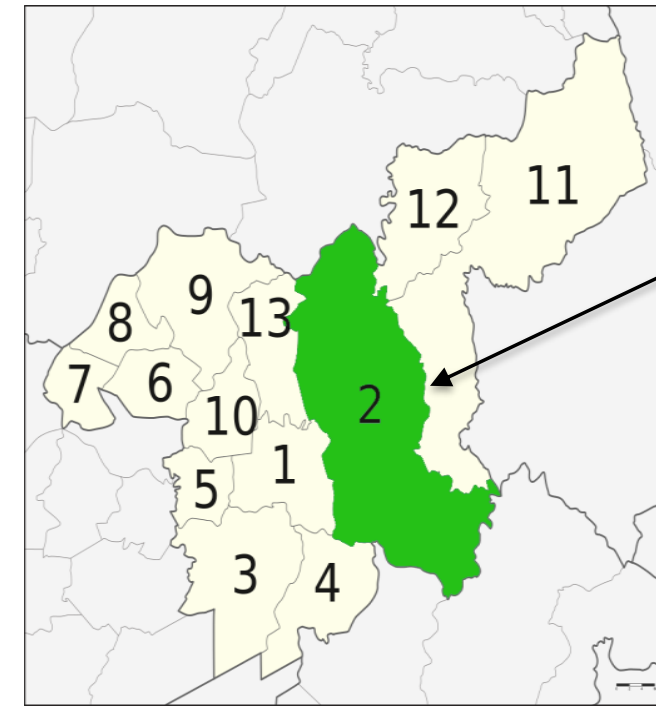

B
13 districts (amphor) of Saraburi province

1. Mueang Saraburi

2. Kaeng Khoi

3. Nong Khae

4. Wihan Daeng

5. Nong Saeng

6. Ban Mo

7. Don Phut

8. Nong Don

9. Phra Phutthabat

10. Sao Hai

11. Muak Lek

12. Wang Muang

13. Chaloem Phra Kiat

Figure 1. Map of Saraburi province, (a) Saraburi province, (b) Amphoe Kaeng Khoi within the study area, (c) 13 districts (amphoe) of Saraburi province (Saraburi province government 2014).

Questions: The research questions comprise a qualitative approach and quantitative approach. The aims of the questionnaires have 4 parts:

Part 1 explores socioeconomic data for the respondents (gender, age, education level, marital status, income, family member, water irrigation, and health).

Part 2 explores farm management (types of livestock, size of farms, sources of feeding rations, costs of production, and income of farms).

Part 3 examines the satisfaction of the respondents about the extension programs (knowledge of livestock rations, sources of education and training practice (academic, government, and private), expectation of the program, and travel distance to the extension center).

Part 4 examines the successes and implications of the program.

Activities of selected farms: The activities of 22 participants were: 1) the cattle rations mixing plan, 2) preparing mixed rations by 22 participants, 3) recording the costs of ingredients, 4) dividing mixed rations to each smallholder based on the number of cattle, 5) recording the time allowing cattle to get to the grass field and getting them back to the farm every day, and 6) weighing the total feeding rations before feeding. Two leaders of the community provided an area to prepare the mixed rations, organized the purchasing of the rations ingredients, and transferred information and knowledge to other farmers. The two leaders participated in activities that differed from the group as follows: 1) weighing cattle every Monday, 2) recording the time allowing the cattle to get to the grass field and getting them back to the farm every day, and 3) weighing the total feeding rations before feeding.

Study Methods: The study began with delivery information, namely, cattle marketing, good-practice cattle farm, and feeding rations management. Also, accounting and feeding cost and knowledge, comprising forage, nutrition grain, alternative grain, and labor provided to farmers. The study involved multiple visits to the farms and in-depth interviews between May 2014 and September 2015. Questionnaires were collected from 22 farms in this area. The questionnaire was designed to obtain basic household information: backgrounding cattle characteristics, age, level of education, farm management and practices, feeding costs, and sources of funds. The characteristics of the backgrounding systems and processes comprising rations, feeding processes, experiences, and household 
sizes were investigated in the interviews. The answers to the questionnaires, the characteristics of the communities and the in-depth interview of the selected leaders were then analyzed.

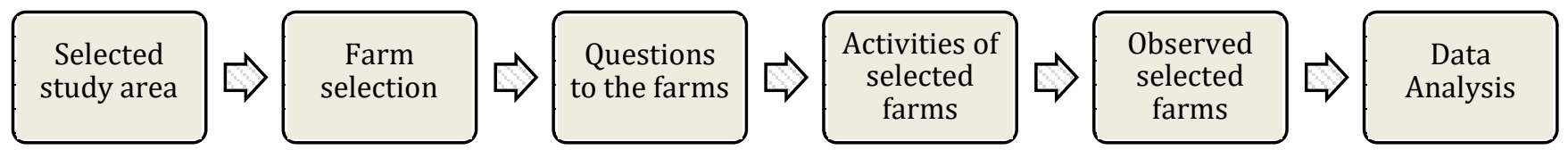

Figure 2. Data selection and analysis process.

Data Analysis: Questionnaires were distributed to the smallholders. The participating farmers completed the questionnaires and two of them were selected to be leaders of this group. Qualitative and quantitative analyses were conducted. Descriptive statistical analysis was used to explain the characteristics of the smallholder cattle farms and their production systems and processes. Comparisons between the pre-program and post- program were recorded and analyzed. The study observed the farms' information before visiting the farm and after visiting the farm in terms of cattle growth rate, the economy of the farm, system management, and social communication. The scale mean value of the highest program satisfaction was 5 .

\section{RESULTS AND DISCUSSION}

Farmers' characteristics and the socio-economics of smallholder cattle farms: The people in the studied area are smallholder farmers. Livestock farms are major forms agriculture in this area and are considered smallholder cattle farms with backgrounding systems. The main production in this area has been based on the backgrounded cattle system, in which cattle are graze on grassland and feed on cheap carbohydrates to develop the muscle and body frame before being sold on to feedlots. Usually, farmers purchase cattle of lighter and smaller frames and backgrounded, finishing at an additional weight of $100 \mathrm{~kg}$ after approximately 3-4 months. The owners spend time in the morning and afternoon allowing the cattle to graze upon the grassland close to their farms. After the cattle return to the farms, they are fed with cheap carbohydrates, dried cassava, pealed cassava, and 8-percent pellet protein.

The study investigated a smallholder cattle farms community which comprised 22 cattle farms. This study included production economics and the sociological aspects of smallholder backgrounding cattle farms. Two community leaders, named Winai-tiwa and Marnop, were chosen to provide information regarding the community farms.

They were selected from 22 households within the farming community to deliver information to the community. The best characteristics of the two farms were the positive attitudes towards acquiring new knowledge, which would benefit the community development process. The study found that the population in this area had incomes below standard and lived in poverty. The major smallholder farmers were between 36 and 45 years old, had kindergarten education level, and had incomes between 5,000 baht to 15,000 baht per year, as shown in Table 1 .

Table 1. Socioeconomics of 22 smallholder cattle farms in Tumbon Tandeaw, Aumphor Kangkoy, Saraburi province, Thailand.

\begin{tabular}{lccccccc}
\hline Gender & $\%$ & Age & $\%$ & Education Level & $\%$ & Income per year (baht*) & $\%$ \\
\hline Female & 65 & Below 15 & 0 & Below Kindergarten & 20 & Below 5,000 & 10 \\
Male & 35 & $16-25$ & 10 & Kindergarten & 55 & $5,000-15,000$ & 45 \\
& & $26-35$ & 15 & Junior High School & 15 & $15,001-25,000$ & 40 \\
& & $36-45$ & 25 & High School & 10 & $25,001-35,000$ & 5 \\
& & $46-55$ & 20 & Vocational School & 0 & $35,001-45,000$ & 0 \\
& & $56-65$ & 10 & Undergraduate & 0 & $45,001-55,000$ & 0 \\
& & More than 65 & 20 & Graduate & 0 & $55,001-65,000$ & 0 \\
\hline
\end{tabular}

*Prices in US dollars, based on the exchange rates at the Siam commercial bank, March 1, 2016.

1 US dollar = 35.92 baht* (Accessed March 1, 2016: http://www.scb.co.th/scb_api/history_exchange.jsp). 
Farm system and farm management: The system and management of smallholder backgrounding cattle farms in this studied area were family businesses with the decision making on investment depending upon family members. The leader of the family took on the tasks of planning, operating, and evaluating activities in the farms. Traditional backgrounding cattle farmers prefer uncomplicated methods in the feeding management process. The farmers allow cattle upon the grassland and feed those cheap carbohydrates, dried cassava, pealed cassava, and 8-percent pellet protein for nutrition after the cattle come back to the farms. The farmers find themselves in a cycle of long-term economic risk, with the trade-off between net return and their feeding system being very difficult to determine. They are at high levels of risk in terms of feeding costs and the cattle market. The costs of feeding are not usually recorded by the farmers. Usually, the farmers depend upon cattle food companies in terms of the rations price and cattle prices in the feedlots market. This is true for the majority of smallholder farms.

Following the program there were socio-economic benefits for the management of the farms. The problem was that the farm owners did not have the adequate technology skills and farm economy knowledge. The production process impacted the costs of production and farm management that had to maximize the profits and efficiency.

Two farm leaders were selected based on the number of cattle, between 30-40, and were better organized than the others. The two leaders had sufficient fodder, labor, and capital and could act as a smallholder farm model in the community. The two leaders of the community farms, Winai-tiwa and Marnop, were interviewed in-depth. The program extension service is shown in Figure 3.
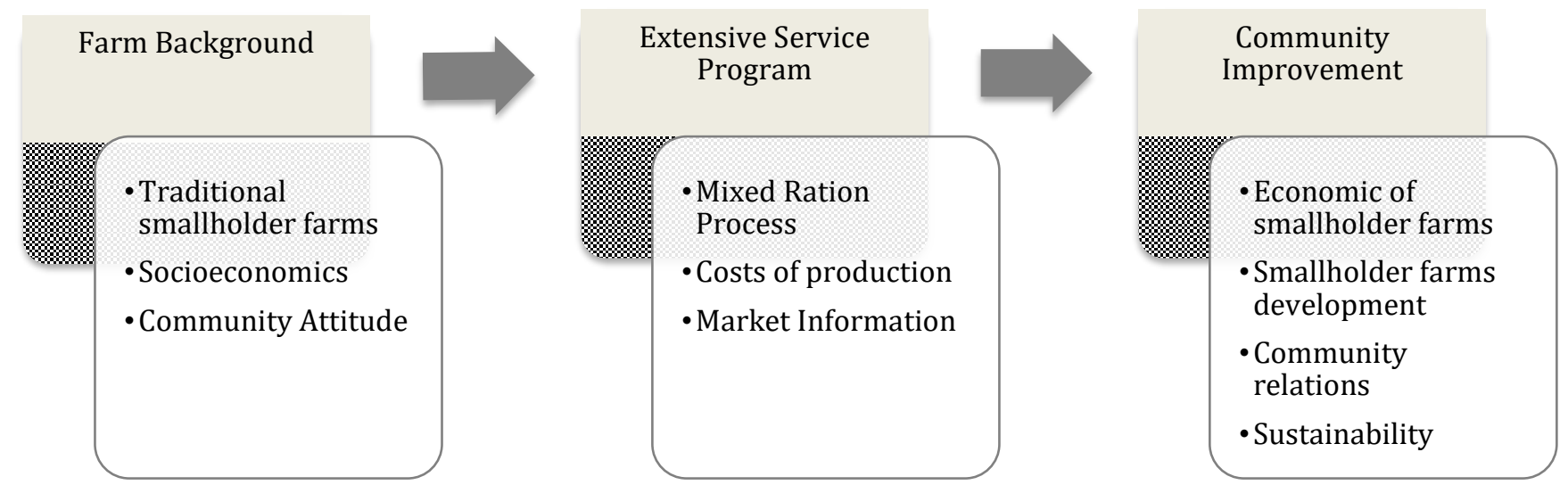

Figure 3. Extension service program management of smallholder cattle farms.

Cattle in rural areas are assets of the household. Income is generated by sale of animals. The farmers in the studied area preferred backgrounding system to feedlot system because livestock in the backgrounding system is an investment and granted for society. Cattle are easy to transfer into cash. The backgrounding systems, temporally, have many benefits because this system is easy to move. This system is appropriate for them in terms of low investment, while a feedlot system involves high investment and complicated management.

The backgrounding cattle system of smallholders usually integrates a mixed crop livestock system and management natural resources (Devandrea \& Thomas 2000c). Smallholder farms have limited supplies of fodder, labor, and capital. Financial support is in high demand within the community. The backgrounding cattle system is a short-term investment for smallholders in rural Thailand. Feeding supply knowledge is neglected in this area because the community has an inadequate number of social scientists as well as insufficient socio-cultural, and community technologies (Paris 2002). The costs of feeding rations are based on large companies in Thailand (Jetmark, 2014). Traditional cattle are fed whatever is available for foraging such as crop residues, grass, and paddle field forage. A sufficient diet is very important for the growth rate. This backgrounding step develops the muscle and frame and thus high quality rations are considered (Perry \& Thompson 2005; Dicostanzo, 2014). The price of cattle is based on the 
estimation of the basis of the physical appearances and beef yield from the live animals. On average, the income of the studied area is below standard, with the population living in poverty as shown in Table 1 . The linkage between farmers and the program is necessary for rural development. Information concerning the feeding supply material generates the largest discount in production costs. Programs encouraging the farmer to reduce feeding costs and use local feed resources enables small farms to become further sustainable.

Generally, smallholder cattle farms in Thailand use backyard production, which is limited to the individual farmers' achievement. Developing backyard farming to economical farming depends upon successful farm organization. The strategic partnership between public extension and the smallholder had benefits for the community. The rural community could improve the socio-economic, socio-cultural, and management aspects in this area.

The backgrounding cattle service program delivered information to farmers in rural areas. This program provided agricultural practices of low economic risks. The program included production, marketing, human capital, and environment management, which helped farmers to manage the farm's labor, investment, and market. Not only was financial knowledge a challenge in this community but also the family and traditional rural society. The community leaders influenced every household. The government and academic programs were delivery to the community. The program expected to increase rural agricultural community relations and living quality standards.

Development from the program: The production process and economic factors were measured and compared between pre-program and post-program. Each step of the process was provided to farmers. According to the study, the feeding ration cost was a major problem for the smallholder backgrounding cattle farm in this studied area. Initially, the program services focused on delivery information and knowledge for the farmers. The costs of animal feeding, animal feeding management, and cattle market were provided to the farms. Next, the mixed rations for cattle feeding were introduced to cattle owners in the process. Farmers were encouraged to work together in the mixed rations process. This process would reduce the costs of the production and build community relations. The steps of ration mixing were provided by the program. An advantage of this program was the measured costs of rations production and the nutrition of the mixed rations. The results showed that the season affected the costs of production and growth rate. Raining season had lower costs of feeding than the others and had higher additional weight per day, as shown in Figures 4 and 5 , respectively.
50000.00

37500.00

25000.00

12500.00

0.00
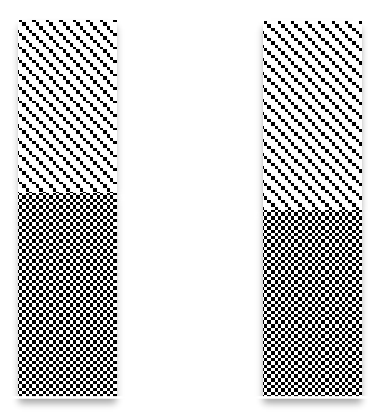

\section{\& After Extension Service Program \\ 垴 Before Extension Service Program}

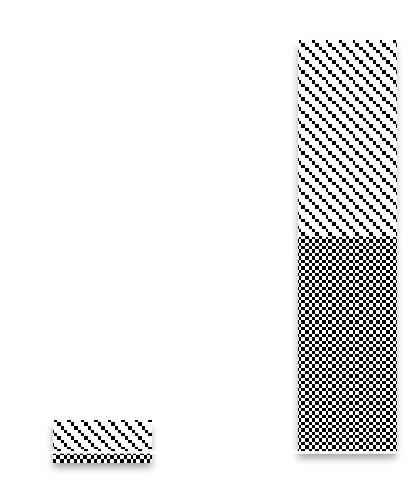

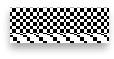

$-12500.00$
Total Cost
Sale Price
Profits per
Total Cost
Sale Price
Profits per
Cattle

Figure 4. Economic changes from the extension program. 


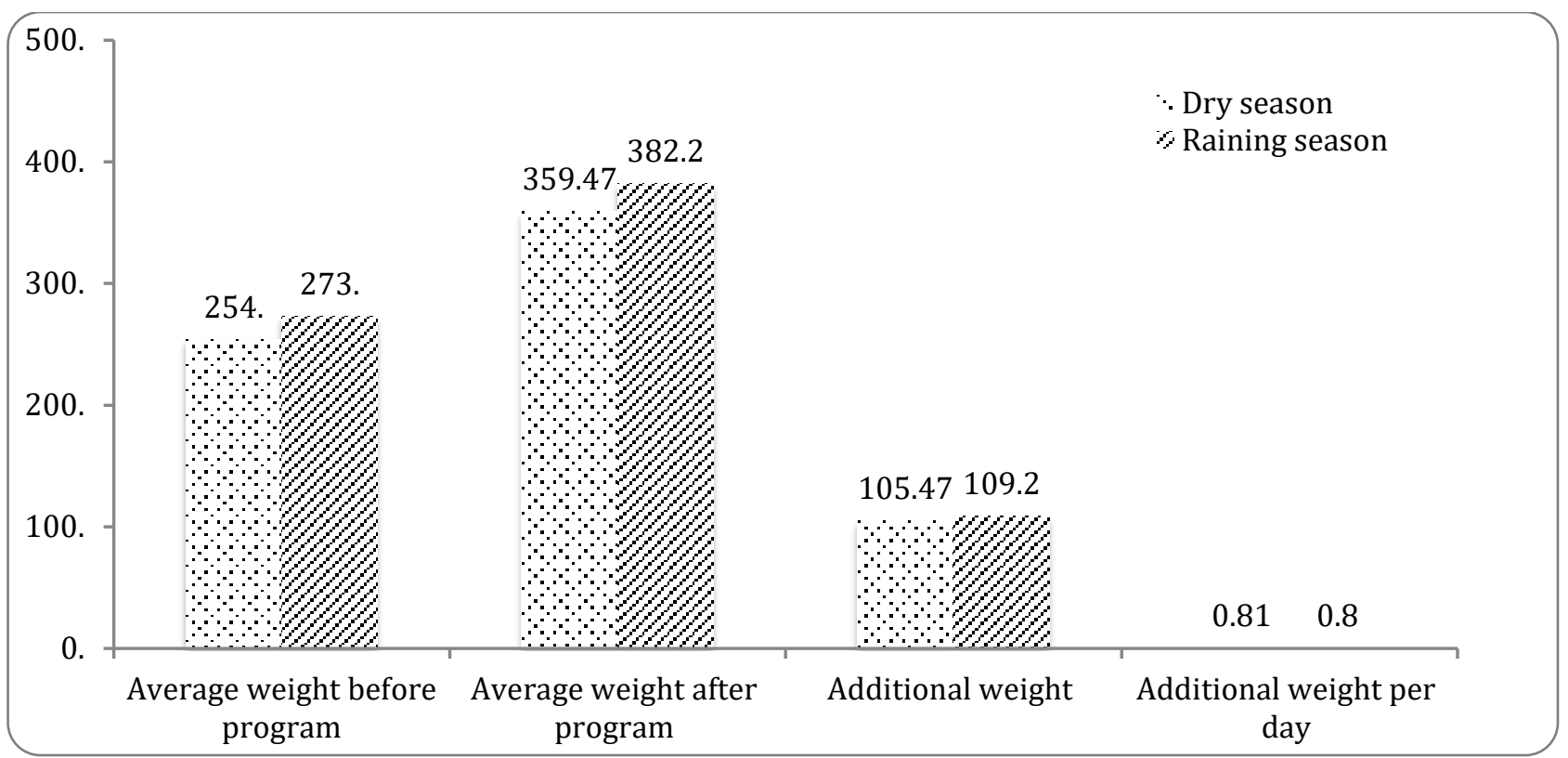

Figure 5. Weight measurement during the extension service program.

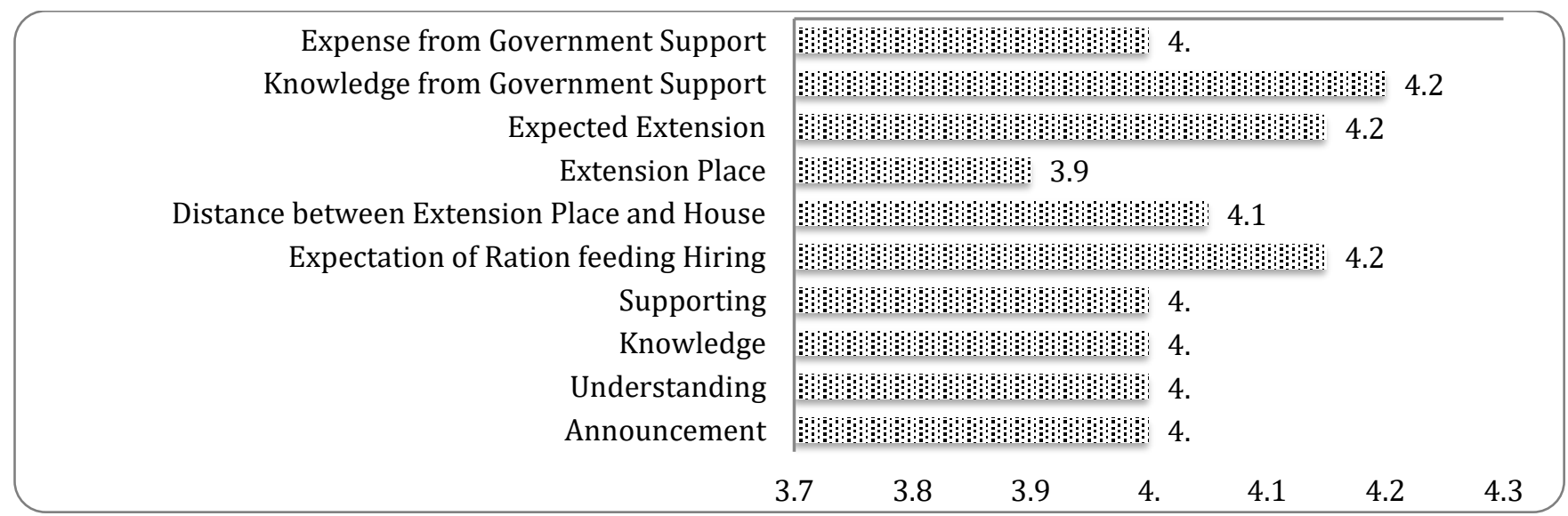

Figure 6. Satisfaction levels of the extension service program.

The culture of the smallholder farms was a major factor affecting the cattle. The community impacted the farm's security by keeping cattle as asset (Dovie et al., 2006). Raising cattle in this society maintained farm security. Farmers in this study kept cattle as assets to generate additional income, which was a social-cultural value and aspect of farm security. This tradition was common in small farms. The cattle played a role in the sustainability and improvement of the farmers' livelihood, economic status, and social status.

The social culture is a major factor influencing agricultural communities in rural Thailand. This affects smallholder farm management systems. The program expected the costs of rations to be reduce by the substitution of local supplies. Price and market was applied in this program and were continued to be used by the community. The smallholder farm development successfully depended upon farm management, especially the community leader. The success of the program depended upon the combination of the local farm community and the commercial farm. They communicated and exchanged information on the market situation. Traditionally, backgrounding farm systems allow cattle to forage for whatever is available and add other low nutrition proteins such as cassava. The farmers face risks on quality and prices of nutrition. After the program, the farmers learned risk management based on the nutrition of the rations. The trade-off between the additional costs of valuable rations and market price benefited the revenue of the community. 
The price of ration ingredients had increased, but the communities purchased together in large amounts and thus the additional prices of supplies were of smaller amount. The community was better-off in terms of farm economics and risks management. The community would join together to develop sustainable rural agriculture. The gap between smallholder and largescale farms was declining because of the communicated relationship programs and pro-active policies. The investment was another means of ensuring the sustainability of the communities.

Implications for national policies: Farmers in the studied area expected that the extension program would improve the economics and quality of life. This program expected farmers to decrease the costs of production and become sustainable smallholders in the backgrounding cattle community. Clearly, smallholder cattle farms preferred to receive government and academic extensions rather than companies. This program increased productivity and improved economic status. The results showed that smallholder cattle farms preferred to decrease the costs of feeding rations by joining the program. The costs of the feeding rations ingredients declined, which depended upon the farm owner management. The program decreased the gaps between individual smallholder cattle farms and the socio-community. This extension was successful in terms of reducing the costs of rations and production per cattle. The farm received approximately 4 times the revenue compared to when the program began. The benefits were directly associated with increased productivity, increased income and the further wellbeing of the society.

Market demand for live cattle has risen in Thailand and neighboring countries such as Vietnam, Lao PDR, and Cambodia (Doyle et al. 2008; Na-Chiangmai 2002; Harding et al., 2007). Smallholder farms have limited resources, for example, financial and production inputs. There exists competition between small and large cattle farms with limited access to the market for smallholders. Smallholder farms are usually not in sustainable markets. Smallholders face high risks in the livestock business; lots of farms have been neglected this, while beef demand has increased in ASEAN markets. Thus, it is necessary the farm system of the smallholder be developed. The development concerns not only the quality and quantity of farm producers but also the costs of production. The challenge of decreasing risk for cattle farm systems is of interest. Smallholders expected to become well managed farms, reducing the costs of production, producing good quality beef, and utilizing sustainable economics.

According to the Department of Livestock Development, DLD, the government encourages the establishment for increasing cattle production for export (DLD 2014). Production technology, natural beef production, and organic beef production are supported and investment is provided for small farms. The government expects to increase both quality and quality. However, the advantages of the studied area indicate that production inputs and capital are too limited to become sustainable. Farm knowledge and farm management are important factors for a strong society. The backgrounding process is the beginning of high quality beef production; thus, the program was provided to develop the farm and improve the quality for the farmers. Groups of smallholder backgrounding cattle farms decline the costs of feed, labor, and the production system. The extension program provided the opportunity for connecting smallholder backgrounding farms to larger farms, and stimulating the development of cattle markets in the area. However, the community group would be further enhanced through developing highquality products and the economic and social aspects of this community.

\section{CONCLUSION}

The backgrounding program of cattle production in Saraburi province, Thailand was limited by foraging, labor, and capital. The studied area used crop-livestock farming systems in terms of cash income and social status. The basic problems of the smallholder farms were the available fodder resources, foraging, management system, and knowledge. The results showed that farm management and household income had risen. However, the estimated profits were not well defined because smallholder farms usually neglected some costs of the production system, which cultural and traditional farming routinely used. Family members played a major role in different activities in the small farms; especially leaders of the family making decisions regarding the farm management. In addition, the study showed that satisfaction towards the extension program (education and training practice) was good; smallholder backgrounding cattle farms followed the knowledge provided. The agricultural extension supported the community to become stronger and more sustainable. In 
order to improve farmers' livelihoods and develop a sustainable farming system, future research should pay more attention to the economic, socio-cultural sector, and government policies. The relationships among the local community, academics, government, financial organizations, and stakeholders should be strengthened in the extension services area.

\section{REFERENCES}

Abdirashid, O. A., K. Intaratat, P. Skunmum and K. Payanum. (2002), "The Integration between the Smallholder Beef Cattle Group and the Large-Scale Farm for Commercial Production", Kasertsart Journal, 23, 185-192.

Anderson, J. R. \& G. Feder. (2002), "Rural Extension Services", Agriculture and Rural Development Department World Bank, Washington, DC.

Arevalo, K. M., M. Ljiung. (2006), "Action Research on Land Management in the Western Amazon, Peru-A Research Process. Its Outcomes and the Researcher's role", Systemic Practice and Action Research, 9,4, 309-324.

Bierlen, R., P.J. Barry, B. L. Dixon \& R. L. Ahrendsen. (1998), "Credit Constraints, Farm Characteristics and the Farm Economy: Differential Impacts on Feeder Cattle and Beef Cow Inventories", American Journal of Agricultural Economics, 80(4), 708-723.

Borge, J.A.R., A.G.I.M. Oude Lansink, C.M. Ribeiro, V. Lutke. (2014), “Understanding farmers' intention to adopt improved nature grassland using the theory of planned behavior", Livestock Sciences, $169,163-174$.

Christian, L., C. Chaikong, J. Maxa, E. Schlecht and M. Gauly. (2012), "Characteristics, socioeconomics benefits and household livelihoods of beef buffalo and beef cattle farming in Northeast Thailand", Journal of Agriculture and rural Development in the tropics and subtropics, 113(2), 155-164.

Comerford, J. W. (2014), "Beef Background Production", available at: http://extensi.psu.edu/business/agalternatives/livestock/beef-and-dairy-cattle/beefbackground-production (Accessed 13 June 2014).

Department of Livestock Development (DLD). (2014), "TMR", available at: http://nutriti.dld.go.th/Nutriti_Knowlage /ARTICLE/ArtileT.htm (accessed 21 May 2014).

Devendra, C. (2002a), "Crop-animal in Asia: Implications for research", Agricultural Systems, 71, 169-177.

Devendra, C. \& D.Thomas. (2002b), "Smallholder farming systems in Asia”, Agricultural Systems, 71,17-25.

De Vries, M., C.E.van Middelaar, I.J.M. de Boer. (2015), "Comparing environmental impacts for beef production systems: a review of life cycle assessments", Liverstock Sciences, 178, 279-288.

Dicostanzo, A. (2014), "Economics of Backgrounding Cattle", available at: http://www.extensi.umn.edu/agriculture/beef/ compents/homestudy/stocker_less6.pdf.

Dinar, A. (1996), "Extension Commercialization; How Much to Charge for Extension Services", American Journal of Agricultural Economics, 78, 1-12.

Dovie, D.B.K., C. M. Shackleton, E.T.F. Witkowski. (2006), "Valuation of communal area livestock benefits, rural livelihoods and related policy issues", Land Use Policy, 23(3), 260-271.

Doyle, P., C. Leddin, N. X. Ba and N. H. Van. (2008), "Improved beef production in central Vietnam. Final Report. Australian Centre for International Agricultural Research, Canberra, Australia", Available at: http://aciar.gov.au/publication/FR2008-21.

FAO. (2015), "Livestock commodities", available at: http://www.fao.org/docrep/005/y4252e/y4252e 05b.htm (Accessed 21 December 2015).

Kamali. F.P., A. Vander Linden., M.P.M. Meuwissen., G.C. Malafaia., A.G.J.M. Oude Lansink., I.J.M. de Boer. (2016), "Environmental and economic performance of beef farming systems with different feeding strategies in southern Brazil", Agricultural Systems, 146, 70-79.

Halim, R.A. and C.P. Chen. (1996), "Feed Resources for Smallholder Livestock Production in Southeast Asia' in Lao P.D.R", Proceeding of the fifth Meeting of Forage Regional Working Group on Grazing and Fee Resources of Southeast Asia, The Food and Agricultural Organization of The United Nations.

Harding, M., D. Quirke, R. Warner. (2007), "Cattle and buffalo in Cambodia and Laos: The economic and policy environment for small holders." Final report. Australian Centre for International Agricultural Research, Canberra, Australia, available at: http://aciar.gov.au/publication/FR2007-215 (accessed 1 June 2007).

Ishmael W. (2014), "Should You Background Your Weaned Calves?", available at: http://beefmagazine.com/health/weaning/shoul d-background-weaned (accessed 21 2014).

Jetmark, Tiwa. (2014), Winai-Tiwa Farm, Interviewed, 1 
May 2014.

Jiumpanyarach, W. (2016a), "Sustainable Development of Farmer Union: Cattle Feed Production of Farmers in Tumbon Tandeaw, Aumphor Kangkoy, Saraburi Province, Thailand", Socially-engaged Scholarship Engagement Thailand, pp. 124-127.

Jiumpanyarach, W. (2016b), "Reduction costs of animal rations for cattle farmers by Participatory Action Research (PAR) in Tumbon Tandeaw, Aumphor Kangkoy, Saraburi Province", Area Based Development Research Journal, 8(3), 68-83.

Livestock Development Branch. (2014), "Backgrounding Beef Cattle in Saskatchewan Livestock Development Branch Saskatchewan Agriculture, Food and Rural Revitalizati", available at: http://www.agriculture.gov.sk.ca/Default.aspx?D $\mathrm{N}=$ 9159a536-5132-4815-ac15-c99d4374dd9e (accessed 21 May 2014).

MaDermott, J.J., S.J. Staal, H.A. Freeman, M. Herrero and J. A. Van de Steeg. (2010), Sustaining intensification of smallholder livestock systems in the tropics, Livestock Science, 130, 95-109.

Marquardt, K. L. Salomonsson, and U. Geber. (2009), "Farmers Facing Rapid Agricultural Land Condition Change in Two Villages in the Upper Amazon, Peru: Can Action Learning Contribute to Resilience?", International Journal Agricultural Resources, Governance and Ecology, 8(5-6), 457-483.

Marousek, G.E., L. D. Stodick, C.Caris, C.C. Gibs. (1994), "Economics of Value- Adding Rangeland Beef Cattle Enterprises", Rangelands, 1(16).

Office of Agricultural Economics (OAE). (2015), "Ration Price", available at: http://www.oae.go.th/ewt_news.php?nid =141\&filename $=$ new (accessed 21 May 2015).

Opgrand, J.J., N. J. Wuldmar., W. E., Tyner. (2016), "Economic viability of lime-treared corn stover in finishing beef cattle diets", The professional Animal Scientist, 33, 73-84.

Na-Chiangmai, A. (2002), "Current situation and development trends of beef production in Thailand. In development strategies for genetic evaluation for beef production in developing countries", Proceedings Australian Center for International Agricultural Research (ACIAR), Canberra, 10, 93-97.

NSO. (2015), “National Statistical office." Bangkok, Thailand. Paris, T. R. (2002), "Crop-animal systems in Asia: Socio-economic benefits and impacts on rural livelihood", Agricultural Systems, 71, 147-168.

Perillat, B.J., W.J.Brown and R.D.H. Cohen. (2004), "A Risk efficiency analysis of backgrounding and finishing steers Pasture in Saskatchewan, Canada", Agricultural Systems, 80, 213-233.

Perry, D. \& J.M. Thompson. (2005), "The effect of growth rate during backgrounding and finishing meat quality traits in beef cattle", Meat Science, 69, 691702.

Pumrukson, Manop. (2014), “Marnop Farm." Interviewed. 1 May 2014.

Reid, D. and G. L. Bradford. (1987), "A Farm Firm Model of Machinery Investment Decisions", American Journal of Agricultural Economics, 69(1), 64-77.

Rich, K.M., R.B.Ross, A. D. Baker \& A. Negassa. (2011), "Quantifying value chain analysis in the context of livestock systems in developing countries", Food Policy, 36, 214-222.

Ror, B., T.C. Haab \& B.Sohngen. (2015), "The Value of Agricultural Economics Extension Programming: An Application of Contingent Valuation", Review of Agricultural Economics, 26(3), 373-390.

Saraburi province government. (2014) "Map." Saraburi Government office. Available at: http://www.saraburi.go.th/new/index.php.

Suzuki, K., M. Kanameda, T. Ogawa, T. T. D. Nguyen, T. T. S. Dang, Q. H. Luu \& D.U. Pfeiffer. (2006), "Productivity and socio-economic profile of dairy cattle farmers amongst rural smallholder communities in northern Vietnam", Livestock Science, 101, 242-250.

Torell, A., R. E. Kirksey, G. B. Dart and J. D. Libbin. (2000), "Economics of Grazing weeping love grass with stickers in the Southern Great Plains", Journal Range Manage, 53,276-268.

Umail-Deininger, D. (1997), "Public and Private Agricultural Extension: Partners or Rivals?", The World Bank Research Observer, 12, 20, 203-224.

Van Asten, P. J. A., S. Kaaria, A. M. Fermont, and R. J. Delve. (2009), "Challenges and Lessons When Using Farmer Knowledge in Agricultural Research and Development Projects in Africa", Experimental Agriculture, 45(1), 1-14.

Watcharathai, R. (2014), "Lung Chaw Farm." Interview, 19 Sept 2014.

World Bank. (2007), "Agriculture for Development", World Development Report 2008. World Bank, Washington, D.C. 